\title{
NILAI-NILAI RELIGIUS DALAM TINDAK TUTUR PADA PROSESI TEMU MANTEN UPACARA PERNIKAHAN ADAT JAWA DI KOTA MADIUN
}

\author{
Ardian Al Hidaya, Alfiati, dan Khoirunnisaa' \\ Sekolah Tinggi Agama Islam (STAI) Madiun \\ (Email: ardwall 999@yahoo.co.id, alfiati88@yahoo.com, ns khoir@yahoo.co.id)
}

\section{Abstract}

In general, this study aims to get a clear description of the events of speech acts in procession Temu Manten Javanese Traditional Wedding Ceremony containing prayers at every stage. The focus of this study include the stages of the procession Temu Manten, meaning each procession Temu Manten, and speech acts that occur at each stage of the procession Temu Manten containing prayers. This study was conducted over 6 months, in the City of Madison. Based on research problems that have been set, the design of the study is a qualitative research design. The study looked at every procession that held in Temu Manten, and seek information from several informants or sources that exist. Informants in this study are the Messiah Rias and Shaman Manten. Data collection techniques used in this research is interview, observation, recording technique, refer to the technical, and engineering notes, whereas the data analysis technique used is an interactive model. From the research findings related to the focus of the research results as follows: (1) the stages of the procession retrieval manten on Marriage Indigenous Java from three different locations in the City of Madison, all of them have a sequence of steps that together, (2) any procession Temu Manten has meaning that contain a request to Allah SWT (3) there is a non-verbal speech acts, namely the prayer said over the heart at any stage in the procession Temu Manten. Thus it can be concluded that there are religious values in the Speech Acts in 
procession Temu Manten Javanese Traditional Wedding Ceremony.

Keywords: religious values, the speech act, Temu Manten

\section{A. PENDAHULUAN}

Masyarakat Jawa pada umumnya hingga kini masih menjunjung tinggi nilai-nilai kebudayaannya. Hal ini terbukti, dengan masih banyaknya tradisi yang mereka lestarikan, seperti upacara pernikahan, Telon-telon, Mitonil Tingkeban, Grebeg Suro, Bersih Desa, Pawang Hujan, dan masih banyak lagi. Salah satu tradisi upacara yang sampai sekarang masih berkembang di tengah-tengah masyarakat Jawa adalah tradisi upacara pernikahan.

Pernikahan merupakan usaha membangun rumah tangga yang muncul dari kemauan manusia akibat olah cipta dan rasa, namun jodoh tetap menjadi urusan Tuhan. ${ }^{1}$ Masyarakat Jawa sebelum menikahkan putraputrinya, biasanya terlebih dahulu memperhatikan bibit, bobot, dan bebet. Bibit di sini maksudnya adalah asal calon menantu, ia dipertimbangkan dari garis keturunan siapa dan bagaimana keadaan/kehidupan calon besan. ${ }^{2}$ Bobot, adalah pertimbangan derajat, pangkat/kedudukan calon menantu serta pendidikannya. ${ }^{3}$ Sedangkan Bebet adalah pertimbangan kelakuan calon menantu, bagaimana keadaan, dan tingkah lakunya. ${ }^{4}$ Setelah mantap dan yakin akan bibit, bobot, dan bebet nya, barulah diadakan upacara pernikahan.

Dalam upacara pernikahan adat Jawa, terdapat banyak ritual, salah satunya yakni tradisi Panggih atau Temu Manten, yang diartikan sebagai pertemuan antara pengantin pria dan pengantin wanita di kediaman pengantin wanita, sebagaimana juga berlaku di masyarakat Kota Madiun, sebuah lingkup masyarakat yang akan menjadi target penelitian.

Tradisi Temu Manten ini, sebagaimana kita sering mengikuti seluruhnya atau sebagian acaranya, banyak tahapan atau prosesi di dalamnya. Prosesi tersebut jika sesuai pakem, maka harus berurutan dari awal hingga akhir,

\footnotetext{
${ }^{1}$ KP. Suwardjoko Proboadinagoro Warpani, Makna Tata Cara dan Perlengkapan Pengantin Adat Jawa, (Yogyakarta:Kepel Press, 2015), hlm.x.

2 bid, hlm.xi.

3 Ibid.

4 Ibid, hlm.x.
} 
tidak boleh ada yang terlewatkan. Selain itu, dalam tahapan-tahapan itu ada semacam tindak tutur atau ucapan simbolis yang sarat dengan doa dan harapan kepada Tuhan karena tidak ada benturan yang berarti antara Islam dan budaya Jawa. Bahkan antara kedua belah pihak nampak saling mendukung dan saling membutuhkan. ${ }^{5}$

Pada hakikatnya, suatu tindakan simbolis dalam upacara keagamaan merupakan bagian yang sangat penting dan tidak mungkin dihilangkan begitu saja, karena ternyata manusia harus bertindak dan berbuat sesuatu yang melambangkan komunikasinya dengan Tuhan. ${ }^{6}$ Religi dalam pengertian luas menjadi kepribadian nasional, selain juga keyakinan ber-Tuhan Yang Maha Esa dan sifat hidup masyarakat lahir batin. ${ }^{7}$

Jadi, hidup bereligi di Indonesia tidak hanya dengan menganut salah satu dari kelima agama yang ada di Indonesia tetapi juga dengan pandangan hidup dari ajaran agama-agama itu. Dari uraian di atas, peneliti meyakini bahwa terdapat banyak nilai religi khususnya dalam penelitian ini dari sudut ajaran Agama Islam, yang diajarkan oleh Sunan Kalijaga untuk mengenalkan Islam kepada masyarakat Jawa, yang dikemas melalui doa-doa yang dipanjatkan pada setiap ritual dalam Tradisi Temu Manten pada Upacara Pernikahan Adat Jawa. Peneliti juga meyakini bahwa masih banyak masyarakat yang belum mengetahui tentang bagaimana prosesi Temu Manten pada Upacara Pernikahan Adat Jawa, yang kaya akan makna dari simbol-simbol dan hiasan dalam upacara pernikahan yang merupakan kekayaan budaya yang memberikan banyak pelajaran hidup serta untuk melestarikan budaya tersebut, maka dari itu peneliti berniat untuk meneliti secara langsung,"Nilai-nilai Religius yang Terkandung dalam Tindak Tutur pada Prosesi Temu Manten Upacara Pernikahan Adat Jawa di Kota Madiun", dengan memilih metode penelitian kualitatif berdasarkan tulisan S.Nasution ${ }^{8}$ yang berusaha mengungkap tahapan, makna simbolik dan nilai-nilai religius yang terkandung dalam tindak tutur pada prosesi Temu Manten upacara

5 Simuh, Keunikan Interaksi Islam dan Budaya Jawa: Makalah dalam Seminar Pengaruh Islam Terhadap Budaya Jawa, 31 Nopember 2000.

6 Budiono Herusatoto dan Suyadi Digdoatmadja, Seks Para Leluhur, (Yogyakarta:CV. QALAM,2004),hlm.193.

Ibid, ,hlm.199.

8 H.B. Sutopo, Metodologi Penelitian Kualitatif, (Surakarta: Sebelas Maret University Press, 2002), hlm. 48. 
Pernikahan Adat Jawa dengan menggunakan pendekatan studi kasus di Kota Madiun. Teknik pengumpulan data yang digunakan dalam penelitian ini, yaitu (1) teknik wawancara; (2) teknik observasi; (3) teknik rekam; (4) teknik simak; (5) teknik catat. ${ }^{9}$ Teknik analisa datanya menggunakan model interaktif dengan cara interaksi dimulai dari pengumpulan data, kemudian peneliti membuat reduksi dan sajian data, kemudian menarik simpulan dan verifikasinya. ${ }^{10}$

\section{B. UPACARA PERNIKAHAN ADAT JAWA}

\section{Pernikahan}

Menikah adalah membangun rumah tangga yang muncul dari kemauan manusia akibat olah cipta dan rasa, namun jodoh tetap menjadi urusan Allah SWT. ${ }^{11}$ Oleh karena itu, peristiwa pernikahan adalah hajat yang amat penting, tidak sembarangan, tidak bisa digampangkan, dengan maksud semoga olah rasa (batin) dan cipta (nalar) yang menumbuhkan karsa (niat) dapat sesuai dengan ketentuan Allah SWT. ${ }^{12}$ Maka dari itu, perihal pernikahan lantas digelar dengan segala adicara sebagai lambang (ungkapan) doa memohon kemurahan Allah SWT. Pernikahan merupakan langkah awal yang menentukan dalam proses membantu keluarga bahagia dan harmonis. ${ }^{13}$ Zaman sekarang dalam mencari dan menentukan jodoh ditentukan oleh calon pasangan yang bersangkutan. Namun demikian orang tua perlu memberi nasehat dan petunjuk putra putrinya dalam mencari dan menentukan jodoh agar tidak salah pilih. Pada umumnya orang tua menginginkan agar putra putrinya mendapatkan jodoh yang serasi agar dalam membangun keluarga mendapatkan kebahagiaan. Bagi orang tua perjaka dan orang tua gadis bila mencari dan menentukan jodoh memberi pedoman yang dinamakan "Triaji”, yaitu "Bibit, Bebet dan Bobot". Meskipun pedoman tersebut merupakan warisan kuno, namun masih cukup

\footnotetext{
9 S. Nasution,Metode Penelitian Naturalistik Kualitatif, hlm. 90 - 98.

${ }^{10}$ H.B. Sutopo, Metodologi Penelitian Kualitatif, hlm. 95.

${ }^{11}$ KP. Suwardjoko Proboadinagoro Warpani, Makna Tata Cara dan Perlengkapan Pengantin Adat Jawa, hlm.x.

${ }^{12}$ Ibid

${ }^{13}$ Thomas Wiyasa Bratawijaya, Upacara Perkawinan Adat Jawa, (Jakarta:Pustaka Sinar Harapan,2006),hlm.3
} 
relevan dalam era modern, hanya penerapannya perlu disesuaikan dengan perkembangan. Yang dimaksud bibit, bebet, dan bobot adalah ${ }^{14}$ :

a. Bibit, yaitu menyangkut faktor keturunan, apakah sang perjaka atau gadis dari keturunan keluarga yang baik atau tidak, biasanya keluarga yang baik akan menurunkan keluarga dan anak yang baik juga dan sebaliknya.

b. Bebet, yang menyangkut perilaku atau budi pekerti dari calon menantu. Adakalanya orang pintar tetapi budi pekertinya amoral dan adakalanya anak pejabat tinggi tetapi kelakuannya jelek, anak orang kaya tetapi kejam dan sifatnya negatif. Bebet yang baik bila anak itu berperilaku sopan santun, rendah hati, berakhlak dan bermoral tinggi, jadi mengenai bebet perlu juga dipertimbangkan.

c. Bobot, yaitu menyangkut kepribadian sang calon menentu termasuk pendididkan, sudah mempunyai pekerjan tetap, memiliki masa depan yang baik atau tidak, penampilannya, watak serta kepribadian yang positif. Jadi bobot ini sangat menentukan kebahagiaan di masa mendatang bila kelak berkeluarga.

\section{Tradisi Panggih atau Temu Manten pada Pernikahan Adat Jawa}

Panggih artinya temu, kepanggih artinya bertemu. Jadi upacara panggih adalah upacara temu antara pengantin putra dengan pengantin putri. ${ }^{15}$ Upacara panggih merupakan upacara puncak dalam perkawinan adat masyarakat Jawa. Dalam upacara panggih pengantin putra dan pengantin putri duduk bersanding yang disaksikan oleh keluarga kedua belah pihak pengantin, dan para tamu undangan.

Pada dasarnya upacara panggih merupakan kesaksian masyarakat dan keluarga bahwa pengantin putra dan pengantin putri secara resmi sudah sah menjadi suami istri. Upacara panggih terdiri atas beberapa tahapan yang setiap tahapan mempunyai nilai rohani dan filosofis serta mengandung harapanharapan agar pasangan pengantin akan hidup berbahagia dikemudian hari.

Upacara panggih beraneka ragam bentuknya sesuai dengan daerah masing-masing. Dalam tulisan ini disajikan upacara panggih dalam bentuk

\footnotetext{
${ }^{14}$ Thomas Wiyasa Bratawijaya, Upacara Perkawinan Adat Jawa, (Jakarta:Pustaka Sinar Harapan,2006),hlm.4

15 Ibid, hlm.118
} 
umum yang satu dengan lainnya saling berkaitan.

Zaman dulu upacara panggih harus dilangsungkan di dalam rumah utama karena rumah-rumah zaman dulu cukup besar dan luas. Rumah tradisional masyarakat Jawa terdiri atas tiga bagian yaitu pendapa dengan lantai bentuk segi empar (bujur sangkar) yang cukup luas berbentuk model "JOGLO". Bagian tengah adalah rumah utama dan bagian belakang untuk dapur, lumbung untuk menyimpan padi dan lain-lainnya.

Ruang pendapa (bagian depan) untuk menerima tamu sedang ruang tengah atau ruang utama dibagi menjadi dua ruangan. Ruang bagian pertama dibagi tiga kamar dan kamar tengah disebut kamar pesucen, yaitu untuk menyimpan benda-benda pusaka seperti keris, tombak dan harta benda yang lain. Kamar tengah tersebut juga digunakan untuk menempatkan sesaji yang bersifat tradisi bagi masyarakat jawa.

Intinya kamar tengah tempat untuk sembahyang untuk memohon kepada Tuhan agar keluarga yang bersangkutan selalu melimpahkan rezeki yang cukup. Secara tradisional kamar tersebut juga dipergunakan untuk penguasa pertanian yaitu Dewi Sri sebagai lambang kesuburan dan kemakmuran.

Sehubungan dengan hal tersebut upacara panggih harus dilangsungkan di depan kamar tengah dengan harapan agar pasangan pengantin kelak diberi rezeki kecukupan. Pada umumnya kamar tengah dihiasi dengan manik-manik, rembe-rembe, kain sutra atau bludru yang disulam atau dibordir dengan motif khas Jawa, sehingga kelihatan indah dan mempesona. Rumah-rumah zaman sekarang terutama di kota-kota besar seperti Jakarta, Bandung, Jogyakarta, Semarang, Surabaya bentuk dan tata ruang sudah berubah sama sekali. Kecuali mereka yang kaya raya, dapat membangun rumah joglo seperti zaman dahulu. Bagi mereka yang memiliki rumah cukup besar dengan halamannya yang luas maka upacara panggih dapat dilaksanakan di rumah meskipun bentuk rumahnya sudah modern.

Tradisi Panggih atau Temu Manten juga dimaknai pertemuan antara pengantin pria dan pengantin wanita di kediaman pengantin wanita. ${ }^{16}$ Acara panggih dilaksanakan setelah ijab atau akad nikah (bagi pemeluk agama Islam) atau sakramen pernikahan/ pemberkatan nikah atau misa bagi

${ }^{16}$ KP. Suwardjoko Proboadinagoro Warpani, Makna Tata Cara dan Perlengkapan Pengantin Adat Jawa, hlm.133. 
pemeluk agama Nasrani (Kristen atau Katolik). ${ }^{17}$ Acara tersebut dilaksanakan secara berurutan dan tidak boleh dibalik.

Upacara panggih merupakan upacara puncak bagi tradisi perkawinan Jawa dan penuh kehormatan. Tanda-tanda kehormatan antara lain :

a. Tempat duduk pengantin dipersiapkan secara khusus;

b. Pengantin bak raja sehari dengan pakaian kebesaran bagai seorang raja;

c. Pada acara panggih para tamu dimohon berdiri memberi penghormatan jalannya upacara pangih;

d. Jalannya upacara pangih diiringi gendhing-gendhing yang khusus untuk pelaksanaan panggih;

e. Selama panggih_tidak boleh disisipkan acara lain, baik hidangan maupun hiburan;

f. Upacara panggih dilaksanakan secara agung dan khidmat

Upacara panggih bertujuan untuk memperoleh pengukuhan secara adat atas perjodohan dua insan yang sudah terikat tali pernikahan, untuk memperkenalkan kepada khalayak (masyarakat) tentang perjadinya perkawinan sekaligus mendapat doa dan restu pada sерири dan semua tamu yang hadir. ${ }^{18}$ Tradisi Temu Manten juga merupakan tradisi yang mempunyai banyak tahap atau prosesi di dalamnya. Terdapat beberapa prosesi dalam tradisi Panggih atau Temu Manten antara lain ${ }^{19}$,

a. Amanat Adicara Panggih yaitu, adicara panggih menjadi pengakuan disaksikan sanak saudara handai taulan bahwa kedua muda-mudi sudah kukuh teguh berumah tangga membangun keluarga serta pengumuman bahwa kedua mempelai akan melangkah memasuki gerbang kehidupan masyarakat.

b. Perlengkapan Adicara Panggihyaitu, pedoman (pakem) perlengkapan panggih yang berlaku antara lain, telur ayam di atas alas irisan daun pandan, air sekar setaman dalam bokor, sindur putih.

c. Adicara Panggih yaitu, pertemuan antara pengantin pria dan pengantin wanita.

d. Pasrah Sanggan yaitu, berupa penyerahan sanggan atau perlengkapan

${ }^{17}$ Suwarna Pringgawidagda. Tata Upacara dan Wicara Pengantin Gaya Yogyakarta. (Yogyakarta: Kanisius,2006), hlm.189

${ }^{18} \mathrm{Ibid}, \mathrm{hlm} .190$

${ }^{19}$ Ibid, hlm.134-148. 
yang dimaknai sebagai pertanda bahwa pengantin siap menanggung segala beban rumah tangga.

e. Liru Kembarmayang yaitu, pertukaran kembarmayang dari pengantin pria yang ditukarkan dengan kembarmayang dari pengantin wanita. Hal ini juga dimaknai sebagai lambang menyingkirkan segala keburukan dengan iringan doa semoga pengantin mendapatkan keselamatan dan kesejahteraan.

f. Balangan Gantal yaitu, Pengantin Pria berjalan lambat diapit sesepuh di kanan kiri, sedangkan pengantin wanita digandeng sesepuh di kanan kiri berjalan sesuai irama gending, sampai depan pintu, kemudian melaksanakan "balangan gantal", gantal terbuat dari gulungan daun sirih berisi pinang atau bunga kantil diikat dengan benang lawe. Makna saling melempar gantal adalah hambalang katresnanantara pria dan wanita, sebagai lambang saling mencintai yang tumbuh dari dalam sanubari atas dasar kejernihan pikiran.

g. Ngunjuk We Wening yaitu, ayah dan ibu pengantin wanita memberi minum air bening kepada pengantin pria dan wanita, yang mengandung makna ajaran agar segala perbuatan hendaknya didasarkan pada pikiran yang jernih, ketajaman nalar, sehingga diperoleh kebahagiaan dan ketentraman.

h. Wiji dadi yaitu, pengantin pria memecahkan telur yang telah disiapkan di bokor yang mempunyai makna bahwa pengantin pria siap menurunkan keturunan.

i. Wijik/ Sesuci yaitu, pengantin wanita membasuh kaki pengantin pria mengandung makna bahwa hanya istrilah yang berhak menentramkan gejolak suami.

j. Bopongan/ Pondhongan yaitu, pengantin wanita dibopong atau digendong pengantin pria menuju pelaminan yang maknanya mencerminkan suami siap bertanggung jawab terhadap istri.

k. Singep Sindur yaitu, pengantin menuju pelaminan dengan digendong oleh ayah pengantin wanita sedangkan ibu mendampingi di belakang pengantin dimaknai bahwa kedua orang tua sebagai contoh atau teladan bagi kedua pengantin.

1. Bobot timbang/pangkon yaitu, ayahanda pengantin wanita duduk di pelaminan, memangku mempelai dikanan kiri, mengandung 
makna bahwa rama ibu menimbang setara antara anaknya sendiri dan menantunya.

n. Ngunjuk Rujak Degan, yaitu kedua pengantin meminum air kelapa muda, hal ini dimaknai bahwa kedua pengantin adalah perjaka menikah dengan gadis dan mengandung doa supaya kedua pengantin segera dikaruniai keturunan.

m. Kacar - kucur yaitu, digelar sebagai amanat kesanggupan suami mencukupi kebutuhan rumah tangga dengan penuh tanggung jawab, diterima istri dalam wadah kacu atau kain tanpa tercecer.

o. Dulangan yaitu, saling menyuapi antara pengantin pria dan pengantin wanita, dimaknai bahwa saling mencintai dan guyup rukun dalam kehidupan berumah tangga.

p Sungkem Hangabekti yaitu, meminta doa restu antara kedua pengantin dengan kedua orang tua dari pengantin pria dan kedua orang tua dari pengantin.

\section{NILAI -NILAI RELIGIUS DALAM TINDAK TUTUR}

\section{Nilai Religius}

a. Pengertian Nilai

Kata nilai dapat dilihat dari segi etimologis dan terminologis. Dari segi etimologis nilai adalah harga, derajat. Sedangkan dari segi terminologis dapat dilihat dari berbagai rumusan para ahli. Nilai adalah keyakinan yang membuat seseorang atas dasar pilihannya. ${ }^{20}$ Tapi perlu ditekankan bahwa nilai adalah kualitas empiris yang seolah-olah tidak bisa didefinisikan. Selain itu, kebenaran sebuah nilai juga tidak menuntut adanya pembuktian empirik, namun lebih terkait dengan penghayatan dan apa yang dikehendaki atau tidak dikehendaki, disenangi atau tidak disenangi oleh seseorang.

Tokoh filsafat zaman pertengahan, Thomas Aquinas, membangun pemikiran tentang nilai dengan mengidentifikasikan filsafat Aristoteles tentang nilai tertinggi dalam diri Tuhan sebagai keberadan kehidupan. ${ }^{21}$

\footnotetext{
${ }^{20}$ Muhammad Fathurrohman, Kategorisasi Nilai Religius, dalam: https://muhfathurrohman. wordpress.com, diakses tgl 03 Maret 2016, hlm 1

${ }^{21}$ Rizal Mustansyir dan Misnal Munir, Filsafat Ilmu, (Yogyakarta:Pustaka Pelajar,2009),hlm.26.
} 
Jadi, nilai merupakan suatu keyakinan atau kepercayaan yang menjadi dasar bagi seseorang atau sekelompok orang untuk memilih tindakannya atau menilai suatu yang bermakna atau tidak bermakna bagi kehidupannya.

b. Komponen Nilai

Runes dalam teori aksiologi menyatakan ada empat komponen penting nilai di antaranya sebagai berikut ${ }^{22}$ :

Pertama, kodrat nilai berupa problem mengenai apakah nilai itu berasal dari keinginan, kesenangan, kepentingan, preferensi, berbagai pengalaman yang mendorong semangat hidup, relasi benda-benda sebagai sarana untuk mencapai tujuan atau konsekuensi yang sungguh-sungguh dapat dijangkau.

Kedua, jenis-jenis nilai menyangkut perbedaan pandangan antara nilai intrinsik, ukuran untuk kebijaksanaan nilai itu sendiri, nilai-nilai instrumental yang menjadi penyebab mengenai nilainilai intrinsik.

Ketiga, kriteria nilai artinya ukuran untuk menguji nilai yang dipengaruhi sekaligus oleh teori psikologi dan logika.

Keempat, status metafisik nilai mempersoalkan tentang bagaimana hubungan antara nilai terhadap fakta-fakta yang diselidiki melalui ilmu-ilmu kealaman kenyataan terhadap keharusan, dan pengalaman manusia tentang nilai pada realitas kebebasan manusia.

c. Religius

Religius berasal dari bahasa Inggris Religious, merupakan kata sifat/ adjectivedari kata Religy. Menurutsuatu pendapat,Religyberasal dari bahasa Latin Relegere yang mengandung arti mengumpulkan; membaca. Agama memang merupakan kumpulan cara-cara mengabdi kepada Tuhan. Ini terkumpul dalam kitab suci yang harus dibaca. Sedangkan menurut pendapat lain, kata itu berasal dari religare yang berarti mengikat. Ajaran-ajaran agama memang mempunyai sifat mengikat bagi manusia, juga dapat diartikan ikatan antara roh manusia dengan Tuhan. ${ }^{23}$

\footnotetext{
${ }^{22}$ Ibid, hlm 27-28.
}

${ }^{23}$ Harun Nasution, Islam Ditinjau Dari Berbagai Aspeknya, Jilid 1, Cet V (Jakarta : UI Press, 1985), hlm.10 
d. Nilai Religius

Berdasar pengertian kata Nilai dan Religus di atas, Nilai Religius bisa diartikan sebagai kualitas atau muatan yang bersifat transendental yang ada pada suatu hal.

Nilai religius merupakan muatan nilai yang memiliki dasar kebenaran yang paling kuat dibandingkan dengan nilai-nilai lainnya. Nilai religius bersumber dari kebenaran tertinggi yang datangnya dari Tuhan dan ruang lingkup nilai ini sangat luas dan mengatur seluruh aspek dalam kehidupan manusia. ${ }^{24}$

\section{Tindak Tutur}

Hymes mengemukakan tiga satuan berjenjang, dari besar ke yang terkecil yaitu, situasi tutur, peristiwa tutur, dan tindak tutur. ${ }^{25}$ Tindak tutur merupakan bagian dari peristiwa tutur, dan peristiwa tutur merupakan bagian dari situasi tutur. Peristiwa tutur terjadi di dalam situasi tutur dan terdiri dari satu tindak tutur atau lebih.

Tindak tutur merupakan perangkat terkecil dalam jenjang yang merupakan derajat paling sederhana dan sekaligus paling sulit. Paling sederhana karena merupakan jenjang minimal dalam perangkat analisis. Paling sulit karena maknanya dalam etnografi komunikasi berbeda dari maknanya dalam pragmatik dalam filsafat, dan karena tindak tutur itu tidaklah cukup minimal. ${ }^{26}$

\section{NILAI-NILAI RELIGIUS DALAM TINDAK TUTUR PADA PROSESI TEMU MANTEN UPACARA PERNIKAHAN ADAT JAWA DI KOTA MADIUN}

\section{Tata Cara Temu Manten atau Panggih}

Upacara Temu Manten/ panggih dengan urutan sebagai berikut :

a. Kehadiran pengantin wanita di depan pelaminan.Setelah itu, pengantin berdiri di depan pelaminan dengan formasi : (1) paling depan Bapak dan Ibu pengantin wanita untuk siap menerima

\footnotetext{
${ }^{24}$ Muhammad Fathurrohman, Kategorisasi Nilai Religius,https://muhfathurrohman. wordpress.com, diakses tgl 03 Maret 2016.hal.10

${ }^{25}$ Sumarsono, Sosiolinguistik, (Yogyakarta: Sabda, 2002), hlm.319.

${ }^{26}$ Ibid, hlm.321.
} 
pisang sanggan, (2) pembawa kembar mayang (dua orang sesepuh), (3) pengantin wanita dan pengapit.

b. Kehadiran pengantin pria didahului beksan edan-edanan 2 pasang pria. Pengantin pria diapit oleh sesepuh/pangeran diiringi Gendhing Bindri. Sesampai didepan tarub berhenti. Pembawa pisang sanggan menghadap orang tua pengantin wanita untuk mengahturkan pisang sanggan.

c. Upacara panggih dilaksanakan drengan iringan Gendhing Ladrang Pengantin. Bertemunya (panggih) pengantin di bawah tarub gapura di depan rumah pemangku hajat. Apabila dilaksanakan di gedung pertemuan, bertemunya pengantin berada beberapa langkah (meter) setelah pintu masuk (jika tempatnya luas dan jalan ke pelaminan agak jauh) dengan tidak mengabaikan keindahan, pakem, dan kemudahan.

d. Pembawa kembar mayang segera menghampiri pengantin pria. Kembar mayang desentuh di bahu kanan kiri pengantin pria. Selanjutnya kembar mayang dibuang di perempatan jalan atau di sungai.

e. Pengantin saling mendekat dan saling melempar gantal, agar tepat pada hitungan saling melempar (pria dan wanita), pengantin pria terlebih dahulu melempar gantal. Lemparan pria diarahkan ke dahi, dada, dan lutut. Lemparan gantal wanita diarahkan ke dada dan lutut pengantin wanita.

f. Ranupada (wijikan), pengantin wanita setelah menghaturkan bakti (sembah ke suami) mencuci kaki (telapak) pengantin pria setuidaknya tiga kali guyuran. Setelah selesai, pengantin wanita menghaturkan bakti dan disambut oleh pengantin. Kemudian, pengantin pria membantu pengantin wanita untuk berdiri.

g. Pengantin berdiri berjajar untuk menuju ke pelaminan.

h. Setelah berdiri jajar, pengantin berjalan menuju ke pelaminan, diiringi oleh Bapak dan Ibunya beserta pengapit. Sesampai di pelaminan, Gendhing Ladrang Penganten suwuk (berhenti secara perlahan).

i. Setelah duduk di pelaminan, upacara tampa kaya dilaksanakan diiringi Gendhing Puspawarna. Pengantin wanita meletakkan tikar yang ditutupi mori (dibuntel) dengan rajutan indah di atas 
pangkuannya. Pengantin pria menuangkan tampa kaya tikar di pangkuan pengantin wanita. Dituangkan sedikit demi sedikit. Tampa kaya berupa kacang kawak, dhele kawak, jagung kawak dan uang logam. Tuangan disisakan sedikit, tidak dihabiskan. Usahakan pengantin menerima tampa kaya tidak ada sedikitpun yang terjatuh.

j. Dhahar klimah : setelah mencuci tangnan, pengantin pria mengepal-epal nasi kuning yang sudah disiapkan oleh perias. Tiga kelapalan kecil-kecil diletakkan di piring yang telah dipegang oleh pengantin wanita. Kepalan kecil-kecil ditambah lauk pindhang antep atau ati antep. Kedua pengantin mencuci tangan, pengantin wanita memakan kepalan nasi disaksikan pengantin pria. Setelah selesai, keduanya minum air bening.

k. Mapag besan: Gendhing Puspawarna sayup-sayup menghilang. Diganti Gendhing Ladrangn Slamet atau Ladrang Sri Wilujeng. Orang tua pengantin wanita berdiri dari tempat duduk (kanan pengantin) untuk menjemput besan. Besan berada dibawah tarub atau di depan pintu masuk gedung pertemuan (jika di gedung). Yang berbesan saling berjabat tangan. Orang tua pengantin wanita menjemput dengan sambutan hangat (pambagya kawilujengan). Para Ibu berjalan di depan, para Bapak berjalan di belakangnya. Pengantin berdiri untuk menyambut kehadiran kedua orang tua mereka. Besan diantarkan duduk disebelah kiri pengantin. Setelah itu, orang tua pengantin wanita kembali duduk di tempat semula.

1. Sungkeman : Setelah kedua orangtua (yang berbesan) duduk di tempat masing-masing. Juru rias segera memberikan kode kepada pengantin pria untuk melepas selopnya, dan keris diambil oleh sesepuh (pria). Pengantin wanita sungkem kepada Bapaknya (orangtua pengantin wanita), kemidian disusul pengantin pria. Diteruskan kepada Ibunya, kemudian menghadap untuk sungkem kepada orangtua pengantin pria. Pengantin pria sungkem terlebih dulu kepada Bapaknya, diteruskan sungkem kepada Ibunya yang diikuti oleh pengantin wanita. Cara sungkem : pengantin menghaturkan sembah terlebih dahulu, kamudian tangan disentuhkan di lutut orangtua, kamudian menyentuh muka (mencium) lutut orangtua, dan diakhiri dengan sembah lagi. 


\section{Makna Simbolik Panggih}

a. Beksan edan-edanan yang mendahului pengantin wanita dan pria. Tarian ini hanya untuk pengantin keraton Yogyakarta. Tarian ini sebagai sarana untuk mengusir bala, roh yang bergentayangan yang akan mengganggu jalannya upacara panggih. Disebut beksan edan edanan (tari gila-gilaan) karena solah tingkah penari seperti layaknya orang gila. Pria yang menari beksan edan-edanan mengenakan kampuh sindur, celana putih, kuluk putih dengan gombyok suwiran janur, wedhung mundhu, dhuwung irus dengan rocen bunga, gelun kelabangan, naik kudo lumping, mandhe lawung/ tumbak atau pedang, srempang cindhe. Tubuhnya dilumuri, mengenakan sumping dan jamang dengan roncen bunga. Wanita yang menari beksan edan-edanan mengenakan kain polos, kampuh sindur, menggendong tenong berisi makanan dan buah-buahan, bersubang lombok merah, gelung munthu dengan diberi bunga, tubuh dilumuri, dan mukanya dibedak tebal.

b. Pisang sanggan: Penyampaian pisang sanggan bermakna: (1) sebagai penebus pengantin wanita; (2) permohonan agar pengantin segera dipanggihkan; dan (3) pernyataan bahwa pengantin pria telah siap untuk dipanggihkan. Disebut pisang sanggan, karena pisang diurai (kerata basa) hanampi gesang. Artinya, pengantin pria telah siap untuk menerima dan mengayomi hidup pengantin wanita.

c. Kembar mayang disentuhkan di bahu kanan dan kiri pengantin pria sebagai pertanda membuang sial (sukreta, bebaya) agar perjalanan hidup pengantin tidak menemui halangan dan rintangan yang berarti sehingga cepat mencapai kebahagiaan hidup.

d. Gantal adalah daun sirih yang bertemu ruasnya untuk membuntal sedikit bunga pinang (jambe), apu (kapur/injet), gambir, tembakau berwarna hitam, diikat benang putih (lawe). Buah pinang tambang keindahan dan keharuman wanita. Kapur berwarna putih lambang kesucian, gambir berwarna kuning tambang kecantikan, tembakau berwarna hitam melambangkan kecocokan hati. Gantal sebagai simbol perjodohan/ pertemuan atu panggih. Walaupun yang satu pria dan yang lain wanita jika telah dilkat dengan tali suci (pernikahan) akan menjadi satu dalam cipta, rasa dan karsa seperti layaknya daun sirih yang berbeda rupa sisi atas dan bawahnya, 
tetapi satu rasa. Lemparan dengan tangan kanan dan kiri. Agar tepat saling melempar (pria dan wanita), pengantin pria terlebih dahulu melempar gantal. Lemparan pria diarahkan ke dahi, dada, dan lutut. Ini menujukkan makna harapan pengantin pria bahwa wanita agar segera dapat mengembangkan dan kuat pikiran (pecah nalar). Biasanya, wanita memiliki perasaan yang lebih kuat dan pada pikiran. Ini dibuktikan jika ada permasalahan wanita lebih cepat menangis dari pada memikirkan solusinya, menangis dutu baru bagaimana penyelesaiannya. Berbeda dengan taki-taki, yang terkadang kebablasan, bertindak dulu baru berpikir akibatnya dengan rasa (perasaan). Oleh karena itu, wajar jika wanita yang pertama melempar gantal pada dada pengantin pna dengan harapan membangkitkan perasaan kasih dan sayang. Segala tindakan juga dirasakan, tidak hanya dipikirkan. Lemparan ke lutut (jengku: krama). Kerata basa dan kata jengku adalah ngajeng-ajeng ing pamengku. Artinya, pengantin (terutama wanita) mengharapkan pengoyoman (pamengku).

e. Ranupada: Ranu berarti air, pada berarti kaki. Ranupada artinya membasuh kaki (wijikan). Ranupada mengandung maksud (1) sebagai tanda bakti istri kepada suami; (2) menghilangkan sukreta (halangan) agar perjalanan menuju keluarga bahagia cepat tercapai; (3) semua tangkah kaki (perbuatan) mendasarkan citacita keharuman, yaitu harum nama keluarga yang dapat dicontoh oleh sesama. Itulah sebabnya ranupada menggunakan air kembang setaman (mawar, melati, kantil). Pengantin pria membantu pengantin wanita untuk berdiri mengandung makna bahwa mereka berdua akan saling membantu dan bersama-sama dalam cita-cita hidup berkeluarga.

f. Pecah telur: Sebelum dipecah, telur disentuhkan di pengantin pria dan wanita. Sentuhan mengandung wiji dadi, yaitu harapan semoga segera diberikan momongan anak (Lambang reproduksi manusia). Selain itu, pecah telur juga mengandung makna harapan bahwa pengantin berdua harus sudah siap untuk berpikir mandiri (pecah nalar, pecah pikir).

g. Pengantin berdiri berjajar untuk menuju ke pelaminan ini menunjukkan kebersamaan seia sekata, satu langkah dalam irama 
untuk mencapai cita, hidup bahagia mahligai rumah tangga.

h. Tampa kaya bermakna: (1) sebagai seorang pria, pengantin pria bertanggung jawab mencari rezeki agar kehidupan keluarga tercukupi; (2) agar pengantin berdua diberi kecukupan, syukur kekayaan; (3) aliran tampa kaya melambangkan rezeki yang terus mengalir, (4) sisa sedikit (tampa kaya tidak dihabiskan) sebagai harapan agan rezeki tidak habis: (5) empon-empon/ dlingo bengle melambangkan hatapan kesehatan; dan (6) bunga-bungaan yang menjadi satu dengan tampa kaya melambangkan keharuman nama; (7) pengantin wanita menerima dengan senang hati dan tampa kaya tidak tumpah melambangkan pengantin wanita memiliki sifat bersyukur, seberapa pun pemberian sang suami akan diterima dengan ikhlas dan syukur kepada Tuhan; (8) tampa kaya tidak ada yang jatuh melambangkan wanita yang berhati-hati dan tidak boros, gemi, nastiti, surti tur ngati-ati 'tidak boros/hemat, cermat, dan berhati-hati'.

i. Tampa kaya melambangkan seorang suami yang tidak curang, semua hasil jerih payahnya diperuntukkan bagi keluarga istri harus pandai mengatur ekonomi ru mah tangga, jangan sampai boros.

j. Dhahar klimah melambangkan kerukunan keluarga, menikmati karunia Tuhan, dan tercukupi pangan-pangan. Lauk pindang atau ati antep melambangkan kemantapan hati atas pilihannya untuk hidup bersama membangun keluarga. Juga melambangkan harapan seorang suami yang memitiki keteguhan hati dan seorang istri yang dapat menjaga rahasia keluarga.

k. Minum air bening melambangkan: (1) pengantin akan saling bertukar pikiran yang dilandasi kebeningan jiwa, tidak ada rahasia; (2) pertemuan wanita dan pria ketika sedang memadu kasih sehingga mengeluarkan kama (necep sarining madu sang munu - menghisap sari patinya madu asmara) yang membawa anugerah anak sebagai tali kasih keluarga.

1. Mapag besan melambangkan penghormatan kepada besan. Maka, kehadirannya sangat dihormati dan dihargai.

m. Sungkeman merupakan isi: (1) tanda bakti anak kepada orangtua yang telah membesarkan dan mendidik hingga dewasa; (2) permohonan anak kepada orangtua untuk membukakan pintu 
maaf atas segala kesalahan anaknya (pengantin); dan (3) memohon doa restu orangtua agar hidupnya (keluarga) berbahagia.

\section{Nilai-nilai Religius dalam Tindak Tutur pada Prosesi Temu Manten Upacara Pernikahan Adat Jawa di Kota Madiun}

a. Pisang sanggan, mengucapkan do'a permohonan agar pengantin segera dipanggihkan.

b. Kembar mayang disentuhkan di bahu kanan dan kiri pengantin pria mengucapkan do'a memohon agar perjalanan hidup pengantin tidak menemui halangan dan rintangan yang berarti sehingga cepat mencapai kebahagiaan hidup.

c. Gantal, mengucapkan do'a memohon auntuk saling mengasihi, Biasanya, wanita memiliki perasaan yang lebih kuat dan pada pikiran. Ini dibuktikan jika ada permasalahan wanita lebih cepat menangis dari pada memikirkan solusinya, menangis dutu baru bagaimana penyelesaiannya. Berbeda dengan taki-taki, yang terkadang kebablasan, bertindak dulu baru berpikir akibatnya dengan rasa (perasaan). Oleh karena itu, wajar jika wanita yang pertama melempar gantal pada dada pengantin pna dengan harapan membangkitkan perasaan kasih dan sayang. Segala tindakan juga dirasakan, tidak hanya dipikirkan. Lemparan ke lutut (jengku: krama). Kerata basa dan kata jengku adalah ngajeng-ajeng ing pamengku. Artinya, pengantin (terutama wanita) mengharapkan pengoyoman (pamengku).

d. Ranupada, mengucapkan do'a memohon agar pengantin wanita/ istri bisa berbakti kepada suaminya dan dalam rumah tangga dianugerahkan kedamaian yang diibaratkan seperti harumnya air bunga.

e. Pecah telur, mengucapkan do'a harapan bahwa pengantin berdua harus sudah siap untuk berpikir mandiri (pecah nalar, pecah pikir) dan kedua pengantin segera dianugerahkan keturunan.

f. Tampa kaya, mengucapkan do'a semoga dalam rumah tangga diberikan rezeki yang halal dan barokah dan semoga sang istri mampu menggunakan hasil jerih payah atau nafkah yang diberikan suami dengan sebaik-baiknya.

g. Dhahar klimah mengucapkan do'a agar dalam rumah tangga 
diberikan kerukunan keluarga, menikmati karunia Tuhan, dan tercukupi pangan-pangan.

h. Minum air bening mengucapkan do'a agar pengantin akan saling bertukar pikiran yang dilandasi kebeningan jiwa, tidak ada rahasia, pertemuan wanita dan pria ketika sedang memadu kasih sehingga mengeluarkan kama (necep sarining madu sang munu - menghisap sari patinya madu asmara) yang membawa anugerah anak sebagai tali kasih keluarga.

$i$. Sungkeman, permohonan anak kepada orangtua untuk membukakan pintu maaf atas segala kesalahan anaknya (pengantin) dan memohon doa restu orangtua agar hidupnya (keluarga) berbahagia.

\section{E. PENUTUP}

Dari hasil penelitian dengan judul "Nilai-nilai Religius yang Terkandung dalam Tindak Tutur pada Prosesi Temu Manten Upacara Pernikahan Adat Jawa di Kota Madiun, maka peneliti dapat menyimpulkan terdapat makna simbolik dari hasil penelitian, dalam setiap tahapan memiliki makna yang dikaitkan dengan properti dan prosesinya serta terdapat doa-doa yang dipanjatkan agar rumah tangga kedua pengantin menjadi bahagia dunia dan akhirat. 


\section{DAFTAR PUSTAKA}

Achmad Chodjim.2009. Sunan Kalijaga. Jakarta: PT. Serambi Ilmu

Basrowi dan Suwandi. 2008. Memahami Penelitian Kualitatif. Jakarta: Rineka Cipta

Budiono Herusatoto dan Sujadi Digdoatmadja. 2004. Seks Para Leluhur. Yogyakarta: CV.Qalam

Harun Nasution, Islam Ditinjau Dari Berbagai Aspeknya, Jilid 1, Cet V (Jakarta : UI Press, 1985), hlm.10

H.B. Sutopo. 2002. Metodologi Penelitian Kualitatif. Surakarta: Sebelas Maret University Press

KP. Suwardjoko Proboadinagoro Warpani. 2015. Makna Tata Cara dan Perlengkapan Pengantin Adat Jawa. Yogyakarta: Kepel Press

Kunjana Rahardi. 2001. Sosiolinguistik, Kode dan Alih Kode. Yogyakarta: Pustaka Pelajar

Lexy J. Moleong. 2007. Metodologi Penelitian Kualitatif. Bandung: PT. Remaja Rosdakarya

Mahsun. 2005. Metode Penelitian Bahasa. Jakarta: PT. Raja Grafindo Persada

Matthew B. Miles, A. Michael Huberman, 1992, Analisis Data Kualitatif, (Terj.) Jakarta: Universitas Indonesia Press.

Muhammad Fathurrohman. 2016. Kategorisasi Nilai Religius (Online). https://muhfathurrohman.wordpress.com, diakses tgl 03 Maret 2016

Rizal Mustansyir dan Misnal Munir. 2009. Filsafat Ilmu. Yogyakarta: Pustaka Pelajar

S. Nasution. 2003. Metode Penelitian Naturalistik Kualitatif. Bandung: PT. Tarsito

Sumarsono. 2002. Sosiolinguistik. Yogyakarta: Sabda

Simuh, Keunikan Interaksi Islam dan Budaya Jawa: Makalah dalam Seminar Pengaruh Islam Terhadap Budaya Jawa, 31 Nopember 2000.

Suwarna Pringgawidagda. 2006. Tata Upacara dan Wicara Pengantin Gaya Yogyakarta. Yogyakarta: Kanisius

Thomas Wiyasa Bratawijaya. 2006. Upacara Perkawinan Adat Jawa, Jakarta: Pustaka Sinar Harapan 
